\title{
Psychological Support for Families During Crises (as exemplified by families members of Ukrainian war veterans)
}

\author{
Wsparcie psychologiczne rodziny w okresie kryzysu \\ (na przykładzie rodzin uczestników działań wojskowych na Ukrainie)

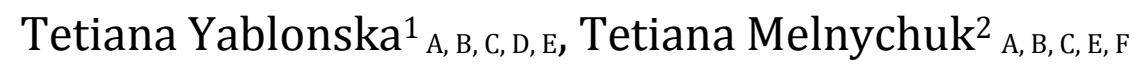 \\ ${ }^{1}$ Developmental Psychology Department \\ of the Taras Shevchenko National University of Kyiv \\ ${ }^{2}$ Social and Organizational Psychology at the Institute of Psychology of G.S. Kostiuk \\ of the National Academy of Pedagogical Sciences of Ukraine
}

\begin{abstract}
The goal of the article is to describe the theoretical and empirical research of characteristics of families under non-normative crises, having as an example the families of combatants participated in the anti-terrorist operation in Ukraine. The following family crises are discussed: normative crises, as period of transition from one stage of the family life cycle to another and non-normative crises caused by traumatic life events.

Research methodology. In order to differentiate more clearly the families of war veterans (those who returned from the antiterrorist operation zone were examined) and their reactions to the crisis, a sample consisted of chosen nuclear families and the attention was focused on the marital subsystem as a family basis. At the end, survey and psychological testing of war veterans' wives were conducted; the following diagnostic techniques were used: the author's questionnaire, FACES-3 method (D.Olson), the questionnaire of family anxiety (E.Eydemiller); the methods of mathematical statistics were used to estimate the data.

Research results. The data of the empirical study of the 36 families of war veterans who participated in the military operations in the ATO zone (Ukraine) show that such non-normative family crisis is characterized by family system imbalance and its correction requires adaptation of the family as a whole system to the new reality. Most war veterans' families undergo series of transformations associated with changes in family structure, communication, significant emotional stress.

Discussion. Psychological assistance to war veterans' families should include psychological learning, prevention and resolving of marital relationship problems, including construction of a new family image, joint life prospects, discussion and transformation of family rules and regulations, development of family cohesion and communication.
\end{abstract}

Keywords: systemic family approach, non-normative crisis, war veterans, family cohesion, family adaptation

\section{Streszczenie}

Celem artykułu jest dokonanie teoretyczno-empirycznych badań dotyczących specyfiki doświadczania przez rodzinę kryzysu nienormatywnego na przykładzie rodzin wojskowych (ATO, Ukraina). Omawiane są kryzysy: normatywne - związane ze zmianą kolejnych etapów cyklu życia rodziny, nienormatywne - spowodowane traumatycznymi wydarzeniami życiowymi.

Metoda badań. W celu bardziej wyraźnej dyferencjacji rodzin żołnierzy (którzy wrócili ze strefy antyterrorystycznej operacji) i ich reakcji na kryzys wybrano próbę badawczą 36 rodzin nuklearnych. Skoncentrowano się na podsystemie małżeńskim jako najważniejszej relacji w rodzinie. W tym celu zbadano żony kombatantów z zastosowaniem narzędzi psychologicznych. Zastosowano następujące metody diagnostyczne: Kwestionariusz autorski, Kwestionariusz FACES-3 (D.Olson), Kwestionariusz Niepokoju Rodziny (E.Eydemiller).

Wyniki badań. Badania nad rodzinami żołnierzy w strefie ATO (Ukraina) pokazują, że kryzysy nienormatywne w rodzinie charakteryzują się zaburzeniem równowagi systemu rodzinnego, natomiast jego korekta wymaga adaptacji rodziny jako systemu do nowej rzeczywistości. Większość rodzin kombatantów doświadcza dyskomfortu związanego ze zmianą w strukturze rodziny, komunikacji oraz znacznego obciążenia emocjonalnego.

Dyskusja wyników. Pomoc psychologiczna dla rodzin żołnierzy powinna obejmować działania psychoedukacyjne, psychoprofilaktyczne w kierunku treningu komunikacji i radzenia sobie z problemami, w szczególności budowy nowego obrazu rodziny, wspólnej perspektywy życia rodzinnego, wspólnych ustaleń odnośnie transformacji rodzinnych norm i zasad funkcjonowania oraz pracę w kierunku rozwoju spójności rodziny.

Słowa kluczowe: systemowa teoria rodziny, nienormatywne kryzysy, kombatant, spójność rodziny, adaptacja rodziny 


\section{Introduction}

Researches on families at different phases of their life cycles are important due to existing necessity for better understanding the features of the modern dynamic rhythm of life and social processes which have a direct impact on family functioning, including an impact of traumatic life events. Thus, recently, Ukrainian families have faced the problem of forced migration, participation in armed hostilities that actualizes the problem of their social and psychological adaptation. That is why developing effective coping strategies for stress overcoming is necessary.

From this perspective, special attention should be paid to war veterans' families. Thus, according to the psychologists dealing with psychological rehabilitation of combatants, such rehabilitation is the most effective if the families are involved as an important resource to support them [1]. In turn, the combatants' families also need psychological support, psychological training, as war veterans returning home, face a significant number of problems. Primarily, they suffer from combat trauma that is manifested as PTSD (posttraumatic stress disorder), depression, anxiety and increased aggressiveness. Thus, according to the International Human Rights Organization "La Strada Ukraine", the national "hot line" received 9135 calls in 2015, out of which $54.4 \%$ were about protection against domestic violence. As many as 38292 calls were received during 2016, $60.3 \%$ of which related to violence and abuse or psychological problems resulting from violence. Moreover, experts say that a number of calls made by women from combatants' families or by those who have seen the war with their own eyes is increasing steadily [2].

Making research on war veteran families, their psychological problems and resources is a prerequisite for development of effective programs of psychological assistance for anti-terrorist operation (ATO) combatants and their families, what is import to develop effective coping strategies for adaptation to peaceful life and family violence prevention.

The article goal is to describe the theoretical and empirical research on characteristics of families under non-normative crises on the basis of the families of combatants participating in the anti-terrorist operation in Ukraine.

\section{Theoretical background.}

The systemic family approach is the most informative one for family studies, within which a family is understood as an open self-organizing system being in constant interaction with the environment, and having resources for development and forming of new concepts within itself (M.Bowen, S. Minuchin, V.Satir and others). Understanding of a family as a complex biological, psychological and social organism allows us to examine all members of this multilevel structure in the context of an integrated system without separation from each other. In practice this means that changes in behaviour of any family member affect the entire family and its other members, as dynamic relationship takes place between the elements of the family system.

It is known that the life of a family system follows two basic laws: homeostasis and development. Trends to preserve the "status quo" confront age and psychological changes of family members (changing of social statuses), their needs and motives reconstruct the life of the whole family functioning and communication. Different stages are distinguished in the family life cycle (J.Haley, O.Chernikov, B. Carter and M. McGoldrick) and families face specific problems and challenges at each of them. Transitions from one stage of the family life cycle to another are normative crises (crises of transition) of the family system and every family experiences such crises. The content of these crises is to resolve conflicts between new challenges and already formed nature of family interactions of its members and requires re-adjustment of the family structural organization, family rule reviewing in accordance with a new situation, and creation of a new family image. Successful transition from one life stage to another ensures further effective functioning and development of the family, while unsuccessful transition can lead to instability in the next stage of family life.

Besides normative crises, a family can experience non-normative crises associated with negative life events. A non-normative family crisis arises from family's inability to adequately assess and live through any event, perceived as threatening, conflicting or stressful, such as death or illness of a family member, adultery, divorce, remarriage, adoption, foster children, teenage pregnancy, escape, etc. [3]. The following components of a non-normative family crisis are distinguished into: a crisis event, perception and understanding of the event by the family members, thwir attitudes and experiences of the crisis event, changes in the family system, possible ways out of the crisis (all members of the family and individual).

A non-normative crisis is characterized by imbalance of the family system; its overcoming requires adapting to the new reality. Family capability to overcome the non-normative crisis depends on its cohesion and available resources to cope with stress. Family features, including rigid and dysfunctional relationship styles, also increase the likelihood of even normative changes being experienced as a family crisis [4].

Participation of a person in armed hostilities and traumatic combat experience have undoubtedly a huge impact on all future activities of this person. A lot of researches are devoted to this theme in the world and in Ukraine. Particularly, the problem of war veterans' rein- 
tegration into civilian life is studied in the works of 0 . Topol [5], A.Karayani [6], while qualitative change of consciousness and a personality meaning core are discussed in the researches of N. Tarabrina [7] and T. Tytarenko [8], whereas psychological assistance for the victims of traumatic crisis events is described in the works of Z. Kisarchuk, G. Lazos, L. Litvinenko [1] and others.

Meanwhile, the family aspect of this problem has not found sufficient attention in psychological researches yet. In particular, as the practice of psychological rehabilitation of combatants and their families shows, there are urgent issues, such as: family adaptation to changes due to mobilization of its members for military service and mutual adaptation of the combatant and his family after his returning from the combat zone, personal and family resources and coping strategies to overcome this crisis, the content and technologies of psychological assistance for the family. Psychological assistance for families of dead soldiers is a separate problem.

Studying of war influence on families, Georgian researchers Z. Beberashvili, D. Javakhishvili and others determined the psychological phenomenon that contributes to creation of a traumatized society - a sense of victimhood [9]. Having this sense of self-sacrifice, demobilized people from the combat zone manifest such negative characteristics as dependence, irresponsibility, passivity, and looking for an enemy in civilian life and experiencing the feeling of offended dignity. The above affect the relationships in their families, as the feeling of "offended dignity" is a painful sense of helplessness and self-destruction, and unimplemented aggression forms the basis for strengthening of the revanchist tendency. Many of such combatants try to evade useful activities, spend all their time in senseless routine, believe that they should not spend time themselves on «small stuff» and should "serve higher ideals», such as «defeating the enemy or restoring of home territories», so their families in everyday life can exist without them. Such attitude creates passive life philosophy of the war veterans and binds their social activity. The above phenomenon lowers men's status not only in their own eyes but in the eyes of their families, children and social environment.

It is fair to say that the family crisis associated with participation of its members in armed hostilities is specific. In addition, such crisis affects all levels of family functioning (structural changes, rules of functioning, family and personal meanings and values). Its development is determined largely by the emotional component increased levels of emotional stress and anxiety. This crisis has a considerable length, starting from the news on mobilization and participation in armed hostilities, includes the phase of actual absence of a family member requiring significant structural and functional restructuring and is also accompanied by high emotional stress. In addition, combatant returning home, although it is a highly anticipated event, is, in fact, experienced as a family crisis, changing again family functioning and starting adaptive processes.

A powerful factor of the family crisis at this stage is a psychological emotional state of the war veteran, changes of his personality that naturally affect family relationships. Thus, according to studies, about $20 \%$ of the combatants have post-traumatic stress disorders, which are generally manifested through a set of symptoms - poor sleep, nightmares, feelings of guilt for having survived, flashbacks (returning to previous experiences, inadequate response at loud shouting or sudden sounds), impairment of their memory, attention, mood depression, frustration. Some combatants are prone to suicide $[10,5,11]$. It is clear that, in the case of serious violations, combatant families also suffer and need information and psychological support.

Even if PTSD is not diagnosed, many combatants have difficulties in adapting to civilian life, what is mainly related to the fact that, as a result of extreme experience, they change their ideas, values, attitudes to reality - all that is content of their core personality, their identity [12]. This is often manifested in the forms of radicalism against the usual "peaceful" orders, heightened sense of justice, a sense that people around them do not understand them, the desire to communicate exclusively with their sworn brothers. The consequences of these processes on the social level can include social isolation, protesting or even antisocial position and alienation, family conflicts and aggression at the micro-social level - the one of their families.

From this perspective, the family environment is critical, as it can become a resource for successful rehabilitation of a war veteran to civilian life through integration of his experience and family support, as well as for aggravation of his negative state and internal conflicts.

\section{Research methodology and sample.}

To study the characteristics of the families experiencing non-normative crisis, 36 families of war veterans returned from the anti-terrorist operation zone was examined. In order to differentiate more clearly the families and their reactions to the crisis, a sample consisting of nuclear families was chosen, the attention was focused on the marital subsystem as a family basis. At the end, survey and psychological testing of war veterans' wives were conducted. The following diagnostic techniques were used: the author's questionnaire, FACES-3 method (D. Olson [13]), the questionnaire of family anxiety (E. Eydemiller [14]) and to estimate the data the methods of mathematical statistics were used. 


\section{Characteristics of the questionnaires.}

The diagnostic scales of family adaptation and cohesion (FACES-3) estimate family system functioning based on two parameters of the "circumplex model" (D. Olson [13]): the family cohesion (a degree of emotional links between family members; they are emotionally interdependent at a maximum intensity of the link, and they are independent and distant from each other at the minimal degree) and the family adaptation, describing how the family is ready to be adapted, to be changed under experience of stresses or traumatic events.

E. Eydemiller's [14] «Analysis of family anxiety» was used to determine features of intra-family relationships and destabilizing factors leading to family functioning disturbance. This method allowed us to detect presence of emotional "markers" of family functional disorders (tension, guilt, anxiety).

The author's questionnaire included 10 questions concerning the situation of men's mobilization to the war zone and their return. In particular, the war veterans' wives were asked to assess emotional response to the news on mobilization with a 10 -point scale, where 10 is the maximum stress intensity, 1 means absence of stress. Several questions revealed emotional experiences during men's stay in the combat zone ("What emotions, feelings did you experience during your husband absence?", "What helped you to cope with anxiety, fear?", "What was the main content of conversations with your husband?"), and after their return home ("Can you say that your family is back to normal life?", "If not, what has changed?", "What problems do you have in relations with your husband now?", "What are the consequences of your husband's participation in the ATO for your family, positive or negative?").

We used content analysis, determination of levels and frequency of characteristics in percentage, Pearson correlation analysis ( $\mathrm{r}$ ).

\section{Research results.}

The survey of war veterans' wives with the author's questionnaire and content analysis of the responses revealed what follows.

The war veterans' wives mainly (55.6\%) indicated that they reacted for the news on husbands' mobilization to the war zone with fear, pain, anxiety, anger: "Terror, the ground crumbled under my feet...". As many as 5.6\% of women marked difficulties to describe emotions they experienced at that moment, the same number of women felt hurting, but they did not show it. It can be assumed that women's reactions to the news on their husbands' mobilization are one of the important indicators of their marital relationships. In particular, $5.6 \%$ of respondents received this news neutrally, and we believe that such answers show existence of some disturbances in their marital relationships. In addition, some women $(16.7 \%)$ indicated that greeted the news well, but this group is heterogeneous in terms of the quality of the family relationship: $11.1 \%$ of women told that they were joyful because "the family would be free from the drunkard", $5.6 \%$ of respondents received the news with joy because "we are the patriots of Ukraine".

Did the news of husband's mobilization into the ATO zone lead to stress responses of his family members? For the most of war veterans' wives, this news provoked strong emotions (Fig. 1): $44.4 \%$ rated it as the highest stress level in the 10 -point scale, $11.3 \%$ of respondents rated it with 9 points, $11.3 \%$ rated with 8 points, $11.3 \%$ did with 5 points, $16.7 \%$ with 4 points, and $5.6 \%$ of women rated with 3 points.

Fig.1. The level of stress caused by the news on husband's mobilization estimated by the war veterans' wives $(n=36)$.

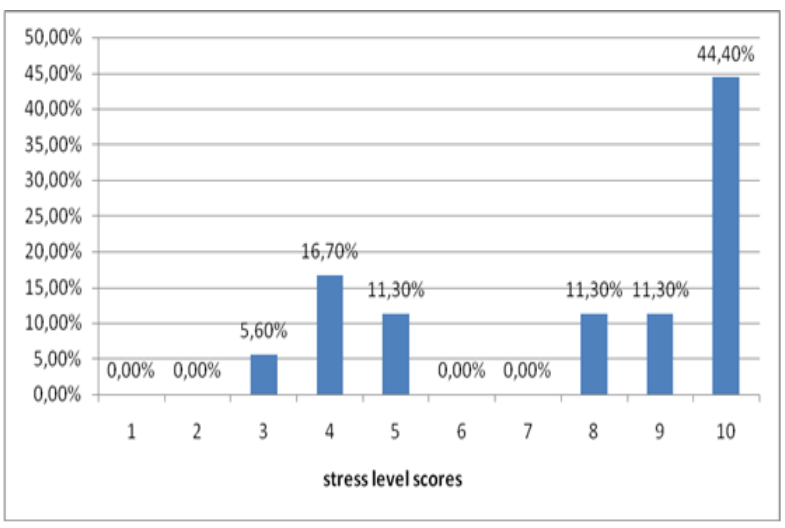

Most women in the time of their husbands' absence were anxious, worried about their lives, some said they felt fear, helplessness, regret, despair. Only 5.6\% of women said that, besides negative feelings, they were also pride.

The ATO participants' wives mentioned the following people and ideas that helped them to cope with anxietyand fear: their parents, children, friends, work, phone conversations with their husbands, as well as "tears", praying, belief that all would be well. During telephone conversations, women tried to encourage the combatants, they discussed future plans and exchanged information about their family, health.

Women's answers concerning family relationships after combatants returning from the ATO zone confirmed that a new phase of family crisis started after the return. Therefore, $72.2 \%$ of women gave a negative answer for the question whether their families had returned to normal life after combatant returning home. The other part of women gave the following responses: "It is hard to say that everything was as before, but we are coping gradually", "Yes, it was difficult, but we have overcome the problem with mutual support", "Changes are not quite noticeable, yet we are trying out handle them, the main thing is support". Among those, at first glance, positive 
responses, there was also: "Returned (to normal life), drink soundly again". Consequently, most war veterans' wives noted significant changes in their family functioning, marital relationship, which is primarily due to consequences of husbands' participation in the armed hostilities.

All the interviewed women, even those who mentioned stabilization of relations, to some extent, stressed that significant changes took place after their husband returned from the ATO zone. Those changes included: changes in their husbands' temper, relations, attitude towards life, people, health, "my husband has become reserved, giving more time to his sworn brothers", "his attitude to children, each other, life has become more complicated", "he does not trust of the state, people, the circle of his friends has been changed", "he is reserved, nervous", "everything has changed". Thus, all women noted changes in the character and attitudes of the ATO participants, which naturally reflected in the dynamics of their relations.

War veterans' wives stressed the following urgent family problems: permanent quarrels, "nerves", distrust, "he does not want to hear me", "he has become a volunteer, takes thing from home to give his sworn brothers, thinks only about them", has become more reserved, "we cannot talk about everything, communicate less with friends". More than a third of the surveyed women reported increased aloofness and nervousness of their husbands.

The women also mentioned positive effects of their husbands' participation in the war, such as higher value of families for the war veterans, "despicable and dishonest people has been fallen away", emergence of new friends, "proud in her husband, children always say that their dad is a Hero", "pride in my husband, respect to him as a defender of our family and the state".

However, most women say that men's participation in the armed hostilities has predominantly negative consequences, both at personal and family levels: disappointment in the events that occurred before his service in the ATO (the Revolution of Dignity), permanent quarrels, separation of spouses from each other, changing of men's behaviour - restrain, communication deficits, alienation from his side, inadequacy, loss of faith in justice. Such negative consequences are mostly confirmed by the correlation analysis, for example, family problems after war veteran returning from the combat zone associated with changes $(\mathrm{r}=0.57, \mathrm{p} \leq 0,05)$ and emotional stress $(\mathrm{r}=0.64, \mathrm{p} \leq 0.05)$.

Research made with Olson's FACES-3 shows that a significant number of the surveyed families are characterized by low cohesion $(66.7 \%$ of families belong to the disengaged type) and the chaotic type of adaptation (55.6\% of families). This indicates considerable distance, aloofness of the family members (especially the men), lack of emotional intimacy, absence of a sense of family unity, excessive flexibility that is manifested in obscurity of the family roles and rules, chaotic family response to difficult life situations. According to the ratio of adaptation and cohesion, the third of the families can be described as unbalanced, characterized by low levels of emotional cohesion and chaotic structure and reaction to difficult situations. The rest of the surveyed combatants' families can be described as mid-range balanced, what means that one of the parameters is optimal, but the other is suboptimal. This situation allows such families to function relatively effectively, but their coping resources are limited. Balanced families among the surveyed ones were not found.

The "Analysis of family anxiety" method shows that a very significant part of the war veterans' wives has the high level of the following parameters: $22.2 \%$ of women feel guilt, $38.9 \%$ are anxious, $55.6 \%$ are under stress, which, according to the family systems approach, can be understood as a manifestation of disturbed family functioning. A characteristic feature of the identified type of anxiety is that it appears in indeterminate fear, fear to lose their significance and "place" in their family, lack of self-confidence or uncertainty of their partners' feelings, helplessness and unbelief in any possibility to change the course of events.

Correlation analysis shows that there is a strong negative correlation between family cohesion and levels of anxiety $(\mathrm{r}=-0.66, \mathrm{p} \leq 0.05)$, guilt $(\mathrm{r}=-0.45, \mathrm{p} \leq 0.05)$, tensions in relationship $(\mathrm{r}=-0.50, \mathrm{p} \leq 0.05)$ and problems $(\mathrm{r}=-0.44$, $\mathrm{p} \leq 0.05$ ), arising after war veteran returning. This means that the families having higher emotional cohesion (it was somewhat low for the chosen sample, not exceeding the boundary optimum level) can provide mutual support, experience less stress and are able to faster overcome the problem. At the same time, emotional stress during the time of combatant recruitment was very high and it correlated positively with cohesion $(\mathrm{r}=0.61, \mathrm{p} \leq 0.05)$. Family adaptation (as an indicator of family flexibility, its ability to adapt to changing situations), according to the correlation analysis, less influences the stress experiencing and overcoming by the families. It correlates with guilt $(r=-0.48$, $\mathrm{p} \leq 0.05)$ and anxiety $(\mathrm{r}=-0.53, \mathrm{p} \leq 0.05)$. This means that feelings of guilt and anxiety become lower with family adaptation growth. This can be considered as a positive coping strategy for families prone to stereotypes and rigid ways of functioning, because it promotes more productive coping with stress and adaptation to new conditions. However, since most surveyed families showed the chaotic level of family adaptation, what leads to confusion and unproductive functioning, such families, in fact, become too shaky (in structures) for the combatants needs, which are, first of all, stability and support, and for other members of their family.

Thus, the performed psychological research has determined that the war veterans' families experience the crisis, which has some peculiarities when it comes to its 
duration, specific manifestations at different stages, delayed effects and which is related, primarily, to traumatic influence and combatants' personal changes. Families with strong emotional bonds and better communication more quickly overcome the effects of stress. They have lower levels of tension, guilt, anxiety, and therefore more resources to overcome the problem. Thus, the families should be researched further as one of the most powerful resources of successful reintegration of the combatants, what confirms extreme importance of psychological assistance for families to strengthen their resources.

\section{Application of the obtained results in practical work with ATO combatants' families.}

The research results suggest that psychological assistance should be provided not only to war veterans but also to their families, including their wives, who face unmotivated aggression, alcohol abuse and do not know how to act when their husbands experience flashbacks. However, much less attention was paid to this aspect of psychological support. Psychological assistance for the ATO combatants is provided by both government agencies and numerous non-governmental volunteer organizations, having a staff of psychologists. However, systematic, purposeful work with families is performed rarely and this work is mainly quite spontaneous, sometimes post factum, in presence of some negative consequences - violence, suicide, etc.

Psychological assistance for war veterans' families can be applied in various areas: mutual adaptation of a veteran and his family, construction of a new family image, joint life prospects, discussion and, if necessary, transformation of family rules and regulations, development of family cohesion and communications.

During the family counselling, firstly, extent to which a family adapts to changes should be checked, how is it flexible to adapt. According to the systemic family approach, there is a continuum from the optimal families (well organized, open to changes) to dysfunctional ones (chaotic, rigid, closed systems that do not interact with the outside world) (D.Olson [13], O.Chernikov[15]). An open and flexible family is more trouble-free and functional, compared to the reserved and rigid family type. Since our research has determined that most families are dysfunctional and have low cohesion and the chaotic type of adaptation leading to breaks in communication, the basic strategy of psychological assistance should be directed to improvement of family cohesion, training of productive coping strategies and constructive communication.

Psychological assistance to the ATO war veterans' families should be implemented in the following areas:

1. Psychological learning: informing and explaining to the war veterans' families on trauma consequences (emotional disorders and PTSD syndrome).
2. Prevention and resolving of marital relation problems and family disharmonies.

Another area, which is not covered within this article, is psychological assistance to ATO war veterans' children, including psychological correction and psychotherapy of emotional disorders, fears and other problems. Psychological assistance to war veterans and their families should be based on the principles of communication, acceptance of a veteran as he is, and professional assistance. The family, as a micro-society, can create conditions so that the veteran does not feel social stigma that leads him to isolation.

As for psychological learning, information about the nature of personal changes under extreme conditions of combat experience is useful for a veteran and his family. Many of such changes are related to combat reflexes and elaborated in life-threatening situations. Family members, especially war veterans' wives, need information that men's behaviour is a delayed reaction to the trauma received under the conditions extreme for the human psyche during armed hostilities. Most war veterans' wives mark also personality changes. The task of a psychologist here is clear: a returned combatant is another person received a unique experience and we should not expect that he will be the same as he had been before. Due to extreme and traumatic combat experience, people change own basic ideas about themselves and the world, reinvent values. The trauma has devastating effects on personal integrity. Some returning home war veterans feel futility and absurdity of everything that happened to them. They think that people are not concerned at all about them, nobody knows about them, they are forgotten. This internal conflict can worsen their condition.

Naturally, a person who has experienced a significant personal transformation, changes relations with others, especially with his family. So, it should not be expected that the relations will be the same as they had been at the micro-level of the family. Returning to civilian life may take a lot of time and it is virtually impossible without family support. War veterans' relatives must understand that despite the signs that may frighten them, they must not retreat because otherwise the veteran will be left alone with his memories, which are sometimes dangerous for his mental health.

In order to prevent and resolve the married couple relationship problems, it is important to teach empathy, understanding of each other's emotional conditions and methods of effective communication. As the experience of psychosocial rehabilitation shows (Khyriv, Lviv region, Ukraine, 2016), women are agents of family changes, namely they usually address a psychologist, are ready to learn, to master the science of communication and support man who suffers from psychological trauma. Those 
war veterans' wives, having mastered certain techniques, can significantly reduce the emotional tension in conflict situations and give support in difficult times. While most war veterans' wives, as our research has shown, also experience stress, their emotional resources, flexibility and relatively less trauma help them overcome the stress more quickly. Self-control, attention, mastering of the conflict management techniques for the cases of aggressive manifestations are especially important for women that will prevent aggression escalation.

A psychologist working with families should remember and inform that, despite the negative impact of traumatic events on the human psyche, positive outcomes are often observed [16]. Thus, many combatants who returned from the war note positive changes such as more meaningfulness, awareness of life, reappraisal of own values, personal growth, self-confidence, selfdetermination. They can determine a stable life position for themselves, reveal new personal meanings and skills, are able not be disappointed in life and people even in the hardest times. They are more than all the others focused on spiritual values, because people who walked on the thin line between life and death can have overwhelming desire to live better than before.

According to the specialists, the effectiveness of rehabilitative psychological influence on a traumatised person is determined by the increase of background, stabilization practices and reduction of extreme risky practices of life construction and by achieving a balance between them (T. Tytarenko [17]). Namely, a family gives a person stability, accepts him/her, what helps the person overcome the trauma.

\section{Conclusion.}

Our research has determined that the war veterans' families experience crisis that has peculiarities when it comes to its duration, specificity of manifestations at different stages, delayed effects, and is related to, primarily, traumatic influence and combatants' personal changes. Families with strong emotional bonds and better communication overcome stress more quickly, as they have lower levels of stress, guilt, anxiety, and therefore, more resources to overcome the problem.

The research results suggest that psychological assistance should be provided not only to war veterans but also to their families, that require specially organized psychological support and psychological learning. Namely, under these conditions, a family can become one of the most powerful factors for successful reintegration of the war veterans, being the most effective tool for their return to civilian life. Therefore, a special study of war veterans' families, identification of their characteristics, specificity of their problems and resources is promising area of scientific research that will contribute to development of effective strategies helping individuals and family of soldiers returning from the combat zones based on their family resources. This will significantly increase effectiveness of psychological rehabilitation of war veterans and facilitate their successful re-socialization.

\section{Conflict of interest}

The authors have declared no conflict of interest.

\section{References:}

1. Kisarchuk S. G., Omelchenko J. M., Lazos G. P., Litvinenko L.I., Tsarenko, L.G.; Psychological assistance to victims of crisis and traumatic events: a guide, ed. G. Karjuk. 2015: 207.

2. Analysis of calls to the National hotline on prevention of domestic violence, human trafficking and gender discrimination during 2016. Electronic resource : http: //la-strada.org.ua/ucp_mod_ news_list_show_608.html.

3. Oliferovich N. I., Zinkevich-Kuzemkina T. A., Velenta T. F. Psychology of family crises. «Speech» 2006: 360.

4. Chernikov A.V. System family therapy: an Integrative model of diagnostics. Moscow 2005.

5. Topol O.V. Socio-psychological rehabilitation of participants of the antiterrorist operation. Bulletin of Cherkasy State Pedagogical University. Cherkassy 2015: 230-233.

6. Karayani A. G. Psychological rehabilitation of combatants, ed. A. Karani, M. Polanski, Military psychology 2004 vol. 3:100.

7. Tarabrina V. A. The psychology of post-traumatic stress. Theory and practice. Moscow: Publishing house "Institute of psychology Russian Academy of Sciences", 2009.

8. Tytarenko T. M. Directions of psychological rehabilitation of the person experiencing events of war. Psychological support of the individual suffering from the effects of traumatic events. Sociopsychological and methodical rehabilitation center, Kiev, Millennium, 2015: 3-13.

9. Beberashvili, Z., Javakhishvili, D., Makhashvili N., Sarjveladze, N. Trauma and psychosocial assistance. A practical guide based on the experience of NGO sof Georgia. Norwegian Refugee Council. Tbilisi-Baku, 2001:13-14.

10. Paronyanc T. P. The emergence and manifestation of posttraumatic stress disorders in employees of the Internal Affairs interms of compliance with UN peace keeping mission (for example former Yugoslavia): dis. of PhD. Kharkiv, 2004.

11. Buryak A.A., Hynevskii M.S., Katerusha G.L. The military syndrome "ATO": the relevance and solutions at the state level. Collection of scientific works of Kharkiv Air Force University. Kharkiv, 2015 vol 2(43): 176-181.

12. Yablonskaya T.M. Development of child's identity in family relationships. Sumy 2013: 444.

13. Olson D. Circumplex Model of Maritaland Family Sistems. Assessing Family Functioning. In Walsh, Froma, Normal Family Processes. The GuilfordPress: NY- London, 1993.

14. Eidemiller E.G. The psychology and psychotherapy of family. SPb: Peter, 2008: 668.

15. Chernikov A.V. System family therapy: an Integrative model of diagnostics, Moscow: Publishing house "Independent firm "Class", 2001. 
16. Klimchuk V. O. Post-traumatic growth and how can we promote it in psychotherapy. Science and education, Odessa South Ukrainian national pedagogical University named K.D.Ushinsky $2016 \mathrm{nr} 5$ : 46-52.

17. Tytarenko T. M. The potential of overcoming difficult life circumstances. Research of social and political psychology, ed. S. D. Maksymenko, N. M. Sliusarevsky and others, Kiev $2006 \mathrm{nr}$ 13(16): 3-13.

\section{Correspondence address}

Тетяна Яблонська: t_yablonska@ukr.net, Тетяна Мельничук: mti_kiev@ukr.net

Otrzymano: 23.05.2017

Zrecenzowano: 25.05.2017, 10.06.2017

Przyjęto do druku: 28.06.2017 